\title{
PENGARUH MANAJEMEN WAKTU TERHADAP HASIL BELAJAR MATEMATIKA SISWA KELAS XII IPS SMA PERGURUAN ISLAM MAKASSAR DI MASA PENDEMI COVID-19
}

\author{
Nana Harlina Haruna ${ }^{1}$, Muhammad Fajar ${ }^{2}$ \\ Universitas Sawerigading Makassar ${ }^{1}$, Universitas Teknologi Sulawesi ${ }^{2}$ \\ nanaharlina86@gmail.com ${ }^{1}$, muhfajar82@gmail.com ${ }^{2}$
}

Abstrak

Penelitian ini merupakan penelitian ex-post facto yang bertujuan untuk mengetahui pengaruh manajemen waktu terhadap hasil belajar matematika siswa di masa pandemic covid-19. Penelitian dilaksanakan di SMA Muhammadiyah 5 Makassar dengan sampel 80 orang siswa. Penelitian ini berlangsung selama pandemic covid-19 sehingga aktivitas pembelajaran dilakukan dengan sistem Daring menggunakan Google Classroom. Hasil penelitian menunjukkan bahwa Hasil belajar matematika siswa kelas XII SMA Muhammadiyah 5 Makassar tahun pelajaran 2020/2021 termasuk dalam kategori Tinggi dengan skor rata-rata 16,8375 atau $38,75 \%$ dari skor ideal 20 yang mungkin dicapai. Manajemen waktu siswa kelas XII SMA Muhammadiyah 5 Makassar berada dalam kategori tinggi dengan skor rata-rata 45,4831 atau $57,28 \%$ dari skor ideal 79,41 yang mungkin dicapai. Manajemen waktu mempunyai pengaruh positif terhadap hasil belajar matematika siswa kelas II SMA Negeri 2 Makassar tahun pelajaran 2020/2021.

Kata kunci: Manajemen Waktu, Hasil Belajar Matematika, Pandemi Covid-19

\section{A. Pendahuluan}

Terdapat dua faktor yang mempengaruhi hasil belajar yaitu faktor internal dan faktor eksternal. Faktor internal merupakan segala sesuatu yang berasal dari dalam diri individu yang mempengaruhi seseorang dalam proses pencapaian prestasi belajarnya, seperti motivasi, minat bakar dan intelegensi. Sedangkan faktor eksternal adalah segala sesuatu yang berasal dari luar individu baik secara langsung maupun tidak langsung yang dapat mempengaruhi seseorang dalam dalam mencapai prestasi belajarnya, seperti faktor lingkungan, sekolah dan masyarakat (Muslimin, T.P., 2016). Dimana kedua factor tersebut haruslah berjalan berdampingan agar hasil yang diperoleh sesuai dengan harapan.

Seringkali untuk mengatasi masalah yang berkitan dengan hasil belajar, banyak siswa mengambil keputusan untuk mengikuti pelajran tambahan yang diadakan oleh lembaga tertentu, padahal permasalahan yang berkaitan dengan 
hasil belajar tersebut berasal dari dalam diri mereka sendiri karena manajemen waktu mereka yang kurang baik.

Manajemen waktu adalah kemampuan seseorang untuk mengalokasikan waktu yang dimiliki dalam membuat suatu perencanaan, penjadwalan, menentukan prioritas menurut kepentingan tanpa menunda-nunda pekerjaan dalam mencapai tujuan yang telah ditetapkan (Fajriayani \& Dhila, 2020). Manajemen waktu yang baik akan menghasilkan sesuatu yang baik pula, seperti hasil belajar yang sesuai dengan harapan dan juga siswa akan semakin menghargai waktu dan menggunakan waktu sebaik mungkin.

Menurut Hudoyo (1990), untuk memaksimalkan hasil belajar perlu pengaturan waktu atau manajemen waktu yang baik karena waktu adalah hal penting dalam mempengaruhi hasil belajar. Peranan manajemen waktu sangat diperlukan dalam memaksimal kan hasil belajar. Siswa harus pandai-panai mengatur waktu mereka seperti waktu untuk belajar, waktu unuk bersantai maupun waktu untuk bermain sehingga waktu belajar mereka tidak terganggu dengan kegiatan lain. Banyak siswa yang kurang memanajemen waktu mereka dengan baik, sehingga waktu belajar mereka terganggu danmengganggu hasil belajar.

Manajemen waktu adalah kemampuan untuk mengalokasikan waktu dan sumber daya untuk mencapai tujuan. Menciptakan keseimbangan antara pekerjaan dan kehidupan pribadi. Manajemen waktu bukan hanya mengacu kepada pengelolaan waktu, tetapi lebih cenderung pada bagaimana memanfaatkan waktu. Seseorang yang mampu mengelola waktu akan menentukan prioritas dari berbagai tugas yang dihadapi, fokus waktu dan energi pada tugas yang penting terlebih dahulu

Awal tahun 2020 menjadi tahun bersejarah untuk seluruh dunia karena wabah Virus Corona atau Covid-19. Wabah Covid-19 masih terus menghantui sejumlah negara di dunia, tak terkecuali Indonesia.

Penyebaran Covid-19 ini pada awalnya sangat berdampak pada dunia ekonomi yang mulai lesu, tetapi kini dampaknya dirasakan juga oleh dunia pendidikan. Kebijakan yang diambil oleh banyak Negara termasuk Indonesia adalah dengan meliburkan seluruh aktivitas pendidikan, membuat pemerintah dan lembaga terkait harus mengahdirkan alternatif lain dari proses pendidikan bagi 
peserta didik (Purwanto \& agus, 2020). Bahkan seluruh jenjang pendidikan menugaskan siswanya untuk melakukan study from home dengan menggunakan media internet. Keputusan tersebut tentunya membawa dampak besar terhadap proses pembelajaran. Siswa tidak terbiasa mengatur waktu belajarnya di rumah, yang sebelumnya separuh waktu mereka habiskan di sekolah tetiba saja mereka harus mengatur waktu belajar mereka sendiri.

Mengatur waktu secara efisien dan efektif bukan sesuatu yang mudah apalagi berupaya untuk mentaatinya secara konsisten. Manajemen waktu merupakan perencanaan, pengorganisasian, penggerakan, dan pengawasan produktivitas waktu. Waktu menjadi salah satu sumber daya unjuk kerja. Sumber daya yang mesti dikelola secara efektif dan efisien. Efektifitas terlihat dari tercapainya tujuan menggunakan waktu yang telah ditetapkan sebelumnya.

Untuk memperoleh hasil yang maksimal, para siswa harus pandai dalam mengatur waktu, seperti waktu untuk belajar, waktu untukbersantai, dan waktu untuk mengerjakan PR. Jangan samapai waktu untuk mengerjakan PR digunakan untuk bersantai hal tersebut akan mengakibatkan menunda mengerjakan PR sehingga PR tidak selesai. Terlebih lagi jika untuk kelas XII dan akan menghadapi banyak ujian untuk kedepannya manajemen waktu merupakan solusi agar medapatkan hasil yang maksimal.

\section{B. Metode Penelitian}

Penelitian ini dilaksanakan di SMA Muhammadiyah 5 Makassar dengan sampel kelas XII IPA Tahun Ajaran 2020/2021 sebanyak 80 orang. Jenis penelitian yang digunakan dalam penelitian ini adalah penelitian Ex-post facto yang menyelidiki hubungan antara manajemen waktu terhadap hasil belajar matematika. Dimana dapat digambarkan hubungan antara variabel-variabel di atas seperti model berikut ini:

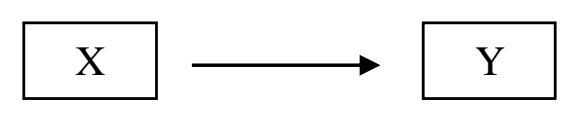

Instrument yang digunakan dalam penelitian ini adalah berupa Angket Manajemen Waktu dan Tes Hasil Belajar. Tes yang digunakan dalam penelitian ini perlu dilakukan uji validitas agar ketepatan alat penelitian terhadap konsep yang 
dinilai sesuai. Dokumentasi yang dimaksud adalah arsip nilai ulangan tengah semester.

Berdasarkan jadwal yang telah ditetapkan, peneliti beserta guru bidang studi matematika menyampaikan beberapa penjelasan yang perlu kepada siswa sehubungan dengan pelaksanaan kegiatan penelitian ini. Dengan dibantu guru bidang studi metematika, peneliti memberikan tes hasil belajar matematika kepada siswa selanjutnya memberikan angket manajemen waktu. Setelah proses pengumpulan data dilakukan, selanjutnya diadakan pemeriksaan dan pemberian skor untuk masing-masing variabel. Untuk tes hasil belajar matematika langsung diberi skor berdasarkan jumlah jawaban responden yang benar. Sedangkan untuk angket manajemen waktu diolah melalui prosedur penskoran untuk mengubah data dari skala Likert ke skala interval. Skor-skor yang diperoleh tersebut selanjutnya dijadikan sebagai data penelitian untuk diolah pada analisis data.

Statistik deskriptif digunakan untuk mendeskripsikan karakteristik data responden. Untuk keperluan tersebut digunakan Tabel distribusi frekuensi, ratarata, standar deviasi dan persentase untuk menyajikan atau mengungkapkan karakteristik distribusi skor responden penelitian

Statistik inferensial digunakan untuk menguji hipotesis penelitian untuk mencari pengaruh variabel bebas terhadap variabel terikat, yang dianalisis dengan menggunakan analisis regresi sederhana pada taraf kepercayaan 95\%. Analisis regresi linear sederhana digunakan untuk mencari pengaruh variabel bebas terhadap variabel terikat. Sedangkan analisis regresi digunakan untuk mencari pengaruh variabel bebas terhadap variabel terikat. Sebelum dilakukan pengujian hipotesis dengan analisis regresi terlebih dahulu dilakukan pengujian persyaratan analisis. Setelah semua persyaratan analisis dipenuhi barulah pengujian hipotesis dilakukan.

\section{Hasil dan Pembahasan}

\section{Hasil}

Hasil analisis statistik deskriptif skor hasil belajar (Y) dapat dilihat pada Tabel 1 berikut:

Tabel 1. Statistik Deskriptif Skor Hasil Belajar Matematika

\begin{tabular}{|l|c|}
\hline Uraian & Nilai Statistik \\
\hline Ukuran Sampel & 80 \\
\hline
\end{tabular}




\begin{tabular}{||l|c||}
\hline Mean (rata-rata) & 16,8375 \\
Standar Deviasi & 2,31912 \\
Variansi & 5,378 \\
Skor Tertinggi & 18 \\
Skor Terendah & 8 \\
Rentang Skor & 10 \\
Median & 12,0000 \\
Modus & 11,0000 \\
\hline
\end{tabular}

Pada Tabel 1. di atas menunjukkan bahwa skor rata-rata hasil belajar matematika adalah 12,8375 atau $64,1875 \%$ dari skor total 20 yang mungkin dicapai. Untuk keperluan interpretasi nilai responden, maka disusun Tabel 2.

Tabel 2. Distribusi Frekuensi dan Persentase Hasil Belajar Matematika (Y)

\begin{tabular}{|c|c|c|c|}
\hline Interval & Kategori & Frekuensi & Persentase \\
\hline $18,00-20,00$ & Sangat Tinggi & 3 & $3,75 \%$ \\
$16,00-17,99$ & Tinggi & 31 & $38,75 \%$ \\
$13,00-15,99$ & Sedang & 27 & $33,75 \%$ \\
$11,00-12,99$ & Rendah & 9 & $11,25 \%$ \\
$0,00-10,99$ & Sangat Rendah & 10 & $12,50 \%$ \\
\hline
\end{tabular}

Tabel 2 menunjukkan bahwa sebagian besar (38,75\%) yang mempunyai hasil belajar matematika dalam kategori Tinggi. Pada Tabel 1 juga ditunjukkan bahwa skor rata-rata hasil belajar matematika yaitu 16,8375. Jika diselaraskan dengan pengkategorian variabel hasil belajar, maka skor rata-rata berada pada interval 16,00 - 17,99. Jadi dapat disimpulkan bahwa hasil belajar matematika siswa kelas XII SMA Muhammadiyah 5 Makassar berada pada kategori Tinggi.

Hasil analisis statistik deskriptif manajemen waktu dapat dilihat pada Tabel 3 sebagai berikut:

Tabel 3. Statistik Deskriptif Skor Manajemen Waktu 


\begin{tabular}{|l|c|}
\hline Ukuran Sampel & 80 \\
Mean (rata-rata) & 45,4831 \\
Standar Deviasi & 10,85692 \\
Variansi & 117,873 \\
Skor Tertinggi & 72,30 \\
Skor Terendah & 17,01 \\
Rentang Skor & 55,29 \\
Median & 45,4750 \\
\hline
\end{tabular}

Tabel 3 menunjukkan bahwa skor rata-rata manajemen waktu adalah 45,4831 atau 57,28\% dari skor ideal 79,41 yang mungkin dicapai. Untuk keperluan interpretasi nilai responden, maka disusun Tabel 4.

Tabel 4 Distribusi Frekuensi Skor Variabel Manajemen Waktu

\begin{tabular}{|c|c|c|c|}
\hline Nilai & Kategori & Frekuensi & Persentase \\
\hline $0,00-8,29$ & Sangat Rendah & 0 & $0.00 \%$ \\
$8,30-25,59$ & Rendah & 5 & $6,25 \%$ \\
$25,60-45,09$ & Sedang & 31 & $38,75 \%$ \\
$45,10-67,50$ & Tinggi & 43 & $53,75 \%$ \\
$67,51-79,41$ & Sangat Tinggi & 1 & $1,25 \%$ \\
\hline
\end{tabular}

Tabel 4 menunjukkan bahwa sebagian besar siswa $(53,75 \%)$ memiliki manajemen waktu dalam kategori tinggi dengan interval 45,10 - 67,50. Pada Tabel 3 juga ditunjukkan bahwa skor rata-rata manajemen waktu adalah 45,4831. Jika diselaraskan dengan dasar pengkategorian variabel manajemen waktu, ternyata skor rata-rata berada pada interval 45,10 - 67,50 dengan kategori tinggi. Maka dapat disimpulkan bahwa manajemen waktu siswa kelas XII SMA Muhammadiyah 5 Makassar dalam kategori tinggi.

Pengujian normalitas bertujuan untuk mengetahui apakah data sampel yang diperoleh dalam penelitian berasal dari populasi yang berdistribusi normal. Berdasarkan hasil analisis data pada pengujian normalitas dengan menggunakan Kolmogrov-Smirnov Normality Test diperoleh $\mathrm{p}=0,059>\alpha=0,05$ yang berarti data sampel berasal dari populasi yang berdistribusi normal, jadi pengujian normalitas dipenuhi. 
Pengujian homogenitas bertujuan untuk mengetahui apakah variansi data sampel memiliki variansi yang homogen atau sama. Berdasarkan hasil analisis data pada pengujian homogenitas dengan menggunakan Test of Nonconstant Variance (Cook Weisberg) diporoleh p-value $=0,0000003<\alpha=0,05$ yang berarti data sampel memiliki variansi yang tidak homogen, jadi pengujian homogenitas tidak dipenuhi.

Pengujian linearitas bertujuan untuk mengetahui apakah persamaan regresi yang diperoleh merupakan persamaan linear. Berdasarkan hasil analisis data pada pengujian linearitas diperoleh $p=0,111>\alpha=0,05$ yang berarti persamaan regresi yang diperoleh merupakan persamaan linear, jadi pengujian linearitas dipenuhi.

Karena ada salah satu pengujian persyaratan analisis yang tidak dipenuhi yaitu pengujian homogenitas maka pengujian hipotesis tidak dapat dilakukan. Oleh karena itu dilakukan pendeteksian data pencilan (outlier). Setelah ditemukan data pencilan tersebut sebagaimana terdapat pada lampiran hasil analisis data maka diperoleh statistik inferensial kedua.

Berdasarkan hasil analisis data pada regresi hasil belajar matematika atas maajemen waktu, diperoleh persamaan regresi sebagai berikut:

$$
\mathrm{Y}=\mathbf{5 , 1 9}+\mathbf{0 , 1 7 2} \mathrm{X}_{2}
$$

Untuk menguji signifikansi model regresi di atas dapat dilihat pada Tabel Analysis of Variance diperoleh F hitung $=109,08>\mathrm{F}$ Tabel $=3,98$ atau $\mathrm{p}=0,000$ $<\alpha=0,05$ yang berarti secara statistik signifikan yaitu $\mathrm{H}_{1}$ diterima atau $\mathrm{H}_{0}$ ditolak. Jadi dapat disimpulkan bahwa terdapat pengaruh manajemen waktu terhadap hasil belajar matematika. Nilai koefisien determinasi yang menyatakan besarnya pengaruh atau sumbangan variabel manajemen waktu terhadap hasil belajar matematika sebesar 59,3\% atau 0,593. Jadi variabel manajemen waktu dapat menjelaskan variansi variabel hasil belajar matematika sebesar 59,3\% .

\section{Pembahasan}

Hasil analisis statistik deskriptif menunjukkan bahwa manajemen waktu siswa kelas XII SMA Muhammadiyah 5 Makassar termasuk dalam kategori tinggi. Dari 80 responden, terdapat 53,75\% siswa yang memiliki motivasi belajar matematika termasuk dalam kategori tinggi dengan skor rata-rata 45,4831 atau $57,28 \%$ dari skor ideal 79,41 yang mungkin dicapai. 
Berdasarkan hasil pengujian hipotesis, maka diperoleh informasi-informasi mengenai pengaruh manajemen waktu terhadap hasil belajar matematika siswa kelas XII SMA Muhammadiyah 5 Makassar.

Pada pengujian hipotesis diperoleh hasil bahwa terdapat pengaruh positif manajemen waktu terhadap hasil belajar matematika siswa kelas XII SMA Muhammadiyah 5 Makassar dengan koefisien determinasi $\left(\mathrm{R}^{2}=59,3 \%\right)$. Hal ini juga sudah sesuai dengan landasan teori sebelumnya yang menyatakan bahwa semakin baik manajemen waktu maka hasil belajar juga akan semakin tinggi.

\section{Kesimpulan}

Hasil belajar matematika siswa kelas XII SMA Muhammadiyah 5 Makassar tahun pelajaran 2020/2021 termasuk dalam kategori Tinggi dengan skor rata-rata 16,8375 atau $38,75 \%$ dari skor ideal 20 yang mungkin dicapai. Manajemen waktu siswa kelas XII SMA Muhammadiyah 5 Makassar berada dalam kategori tinggi dengan skor rata-rata 45,4831 atau 57,28\% dari skor ideal 79,41 yang mungkin dicapai. Manajemen waktu mempunyai pengaruh positif terhadap hasil belajar matematika siswa kelas II SMA Negeri 2 Makassar tahun pelajaran 2020/2021.

\section{Daftar Pustaka}

Fajhriani, Dyla. (2020). Manajemen Waktu Belajar di Perguruan Tinggi pada Masa Pandemi Covid-19. JIEMAN: Journal of Islamic Educational Management, 1(3).

Hudoyo, H. (1990). Strategi Belajar Mengajar Matematika. IKIP Malang.

Jusmiana, A., Herianto, H., \& Awalia, R. (2020). Pengaruh Penggunaan Media Audio Visual Terhadap Hasil Belajar Matematika Siswa Smp Di Era Pandemi Covid-19. Pedagogy: Jurnal Pendidikan Matematika, 5(2), 1-11.

Muslimin, T. P. (2016). Pengaruh Metode Recollection Smart Teaching (RST) Terhadap Minat Belajar Mahasiswa Melalui Lesson Study. Prosiding, 2(1). Purwanto, Agus dkk.(2020) "Studi Eksploratif Dampak Pandemi Covid-19 Terhadap Proses Pembelajaran Online di Sekolah Dasar. EduPsycouns: Journal of Education, Psychology and Counseling. 2(11)

Ruseffendi, E. T. (1990). Pengajaran Matematika Modern dan Masa Kini. Bandung: Tarsito.

Safuni, N., Hidayati, H., \& Fitriani, N. (2020). MANAJEMEN WAKTU SELAMA 
PANDEMI COVID 19 PADA MAHASISWA KEPERAWATAN DI KOTAMADYA BANDA ACEH. Idea Nursing Journal, 11(1).

Slameto. (1987). Belajar dan Faktor-Faktor yang Mempengaruhinya. Jakarta: Rineka Cipta. 